ELORE (ISSN 1456-3010), vol. 19 - 1/2012.

Julkaisija: Suomen Kansantietouden Tutkijain Seura ry.

[http://www.elore.fi/arkisto/1_12/lepola.pdf]

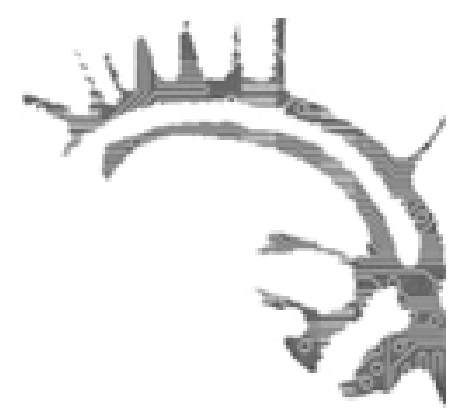

\title{
KIRJA-ARVIO
}

\section{VALKOISEN INTIAANIN KIRJAVA ELÄMÄ}

SALOMAA, ILONA 2011: Valkoinen intiaani. Tutkimusmatkailija Rafael Karstenin elämä. Helsinki: SKS. 296 sivua.

$\underline{\text { Marcus Lepola }}$

Valkoinen intiaani on suomalaisen kansatieteilijän ja uskonnontutkijan Rafael Karstenin elämänkuvaus. Karsten tunnetaan parhaiten hänen varhaisista ja rohkeista tutkimusmatkoistaan Gran Chacon alueen intiaanien pariin, mistä kirjan nimikin juontuu. Kirjan tekijä, uskontotieteen tohtori Ilona Salomaa on jo lähes kahdenkymmenen vuoden ajan tutkinut Rafael Karstenin tutkimustyötä ja sen merkitystä uskontotieteen kehitykselle. Salomaa on urallaan tutustunut Rafael Karstenin elämään syvällisemmin kuin kukaan muu tutkija. Hänen työtään on edesauttanut Karstenin jälkeläisten myötämielisyys ja tuki. Valkoinen intiaani on Salomaan mukaan syntynyt ajatuksesta esittää Rafael Karstenin elämää väitöskirjaa (2002) populaarimmassa muodossa. Salomaa koki, että akateemisen tyylin edellyttämä niukkasanaisuus oli rajoittanut hänen aiempaa kuvausta Rafael Karstenin elämästä.

Valkoisessa intiaanissa Salomaa on pyrkinyt esittämään Karstenia kahdessa kontekstissa: monien henkilökohtaisten vaikeuksien riivaamana yksityishenkilönä sekä uraa uurtavana antropologina. Mielestäni Salomaa on onnistunut pyrkimyksissään, sillä hänen kirjansa ei ole jähmeä teos, vaan se imaisee lukijan mukaansa Karstenin monivivahteiseen elämäntarinaan jo alkusivuistaan saakka. Lukijan on helppo seurata 
Marcus Lepola: Valkoisen intiaanin kirjava elämä

Karstenin eri elämänvaiheita, sillä Salomaa on hyvän historioitsijan tavoin onnistunut asettamaan Rafael Karstenin tutkimustyön ja yksityiselämän vaiheet osaksi suurempaa kokonaisuutta. Kirjaa ei voi siis mieltää pelkkänä matkakertomuksena Gran Chacon alueella tehdystä kenttätyöstä, vaikka suuri osa tekstistä käsitteleekin Karstenin useita tutkimusmatkoja. Esimerkiksi Rafaelin hankala suhde oppi-isäänsä Edvard Westermarckiin ja kollegaan Gunnar Landtmaniin saa osakseen paljon huomiota. Salomaa kirjoittaa myös Karstenin ja ruotsalaisen kansatieteilijän Erland Nordenskiöldin välisestä tuttavuudesta ja myöhemmästä välirikosta. Sisällöltään kirja mukailee Salomaan väitöskirjaa, mutta ei suinkaan ole suora käännös hänen aiemmasta työstään.

Salomaa on erinomainen kertoja: lukijalle välittyy Karstenin uran alkutaipaleen monet lannistavat ongelmat liittyen perhesuhteisiin ja puuttuvaan rahoitukseen. Suomessa vallitseva vaikea poliittinen tilanne pakotti nuoren Karstenin ulkomaille pakoilemaan Venäjän armeijan kutsuntoja.

Karstenin uran alkuvaiheen toistuvat pettymykset luovat hyvin dramaattisen kuvan sinnikkäästä ja jopa jääräpäisestä kansatieteilijästä, joka rahaongelmistaan huolimatta onnistui matkustamaan Etelä-Amerikkaan ja myöhemmin myös luomaan uraa kansainvälisesti tunnustettuna kansatieteilijänä. Moni nykyinen tutkija varmasti tunnistaa itsensä Rafaelin Karstenin elämästä ja hänen huojumaton sitkeytensä on inspiraation lähde monille arjen rahaongelmien kanssa painiville tutkijoille.

\section{RAFAELIN RUOTSINKIELINEN IDENTITEETTI}

Eloisasta kerronnasta huolimatta osa Rafael Karstenin henkilökuvasta jää minulle etäiseksi. Tämä liittynee omaan taustaani, joka vaikuttaa suuresti siihen, miten hahmotan Karstenia henkilönä. Olen Karstenin tavoin kotoisin ruotsinkieliseltä Pohjanmaalta ja näin ollen en voi olla huomioimatta tätä taustaa hänen moninaisessa henkilökuvassaan. Salomaalta jäävät jotkin paikallistaustaan liittyvät nyanssit huomioimatta. Moninaisten ruotsinkielisten murteiden ja vahvojen paikallisidentiteettien värittämä Pohjanmaa oli, ja on yhä, hieman erillään Helsingin vaikutuspiiristä ja sosiaalisista verkostoista. Taustoilla ja verkostoilla oli suuri rooli akateemisen valtapelin käydessä kuumana. On todennäköistä, että Karstenin pohjanmaalaisella taustalla oli ainakin hänen uransa alkutaipaleella rajoittava vaikutus. Mahtoiko tästä olla todisteena Karstenin vaatimaton arvosana filosofian kandidaatin ruotsin kielen kokeessa 1901? Olisikohan nuoren ylioppilaan kotikieli, kvevlaxmålet vaikeuttanut puhtaan ruotsin kielen sujuvaa puhumista?

Koen, että kirjassa esiintyvät suomeksi käännetyt suorat sitaatit Karstenin ja hänen perheensä välisestä kirjevaihdosta peittävät alleen Karstenin ruotsinkielisen identiteetin. Mielestäni henkilökohtaisen kirjeenvaihdon sitaatit olisi voinut sijoittaa alkuperäisessä kieliasussaan esimerkiksi teoksen loppuviitteisiin. Lainausten esittäminen vain suomeksi on Karstenin kokonaisvaltaisen henkilökuvan kannalta huono ratkaisu. Sellaiset kirjassa esiintyvät oudot suomennokset, kuten muurmuur (mormor) eivät mielestäni ainakaan paranna tätä epäkohtaa. 
Marcus Lepola: Valkoisen intiaanin kirjava elämä

Tästä huolimatta Valkoinen intiaani on tasapainoinen ja hyvin kirjoitettu teos Rafael Karstenin elämästä. Se tarjoaa mukavia lukuhetkiä muillekin kuin antropologiasta ja sen lähialoista kiinnostuneille.

\section{KirjallisuUs}

SALOMAA, ILONA 2002: Rafael Karsten (1879-1956) as a Finnish Scholar of Religion. The Life and Career of a man of Science. Helsinki: omakustanne.

Filosofian maisteri Marcus Lepola työskentelee väitöskirjansa parissa Åbo Akademin kansatieteen oppiaineessa. 